\title{
Recent Evidence of Probable Breeding of the Japanese Murrelet Synthliboramphus wumizusume on Tori-shima, Izu Islands, Japan
}

\author{
Miyako Tsurumi*1), Fumio Sato*, Takashi Hiraoka* \\ and Ryo Maeyama**
}

Key words: breeding, carcass collecting record, Japanese Murrelet, Synthliboramphus wumizusume, Tori-shima.

キーワード：繁殖，死体拾得，カンムリウミスズメ，伊豆諸島鳥島.

The Japanese Murrelet Synthliboramphus wumizusume is the rarest and most threatened species of the alcids (Nettleship 1996), with small populations breeding on small islands off the Japanese Archipelago and off southern Korea (Ono 1995, 1996, 1998). This species once bred on Tori-shima in the Izu Islands $\left(30^{\circ} 28^{\prime} \mathrm{N}, 140^{\circ} 18^{\prime} \mathrm{E}\right)$, (Momiyama 1932, Yamashina 1936, 1942, OSJ 1942, 1958, 1974, Kiyosu 1952), and 9 study skins (7 adults and 2 chicks) and 7 clutches of eggs collected from Tori-shima from 1930 to 1935 are kept in the Yamashina Institute for Ornithology. However, to our knowledge, there has been no record of its having bred on Tori-shima since 1935 (Ono 1955, Kawada 1956, Aronof 1960, Hasegawa 1984) except for a record of eggshell presumably of this species collected in 1994 by H. Hasegawa (Ono 1995). In this note, we report recent evidence of probable breeding at Tori-shima, including the discovery of a dead egg-laying female in 2000 and nocturnal vocalizations in $2000-2001$.

Since 1991, the Yamashina Institute for Ornithology has been conducting a restoration project on the Short-tailed Albatross Diomedea albatrus on Tori-shima, using decoys and vocal lures. Since 1993, observations have been made each year of the behaviour of Short-tailed Albatrosses in relation to the decoys for a period of about one week to ten days during February (Sato et al. 1998). In 2000 this fieldwork was delayed to the period from 23 February to 7 March due to bad weather conditions. In addition to this February fieldwork, we visit the island for about 10 days in October every year to set up the decoys and again for about ten days in May to stow them away.

On 4 March 2000 at 5:00, the calls of several Japanese Murrelets were heard near our base camp at Hatsune-zaki in the western part of the island. A search later that day along the rocky cliffs of Hatsune-zaki resulted in the discovery of a freshly dead individual of this species among the rocks at an elevation of about $20 \mathrm{~m}$ above sea level (Fig. 1a). The dead bird was found among large volcanic rocks piled up at the foot of an almost vertical rocky cliff. Fragments of broken eggshell were attached to the external abdomen of

Received 16 April 2001, Revised 14 June 2001, Accepted 21 June 2001.

* Yamashina Institute for Ornithology, 115 Konoyama, Abiko, Chiba 270-1145 Japan.

** 8-19-16 Koganehara, Matsudo, Chiba 270-0021 Japan.

1) Corresponding author: E-mail: tsurumi@yamashina.or.jp 

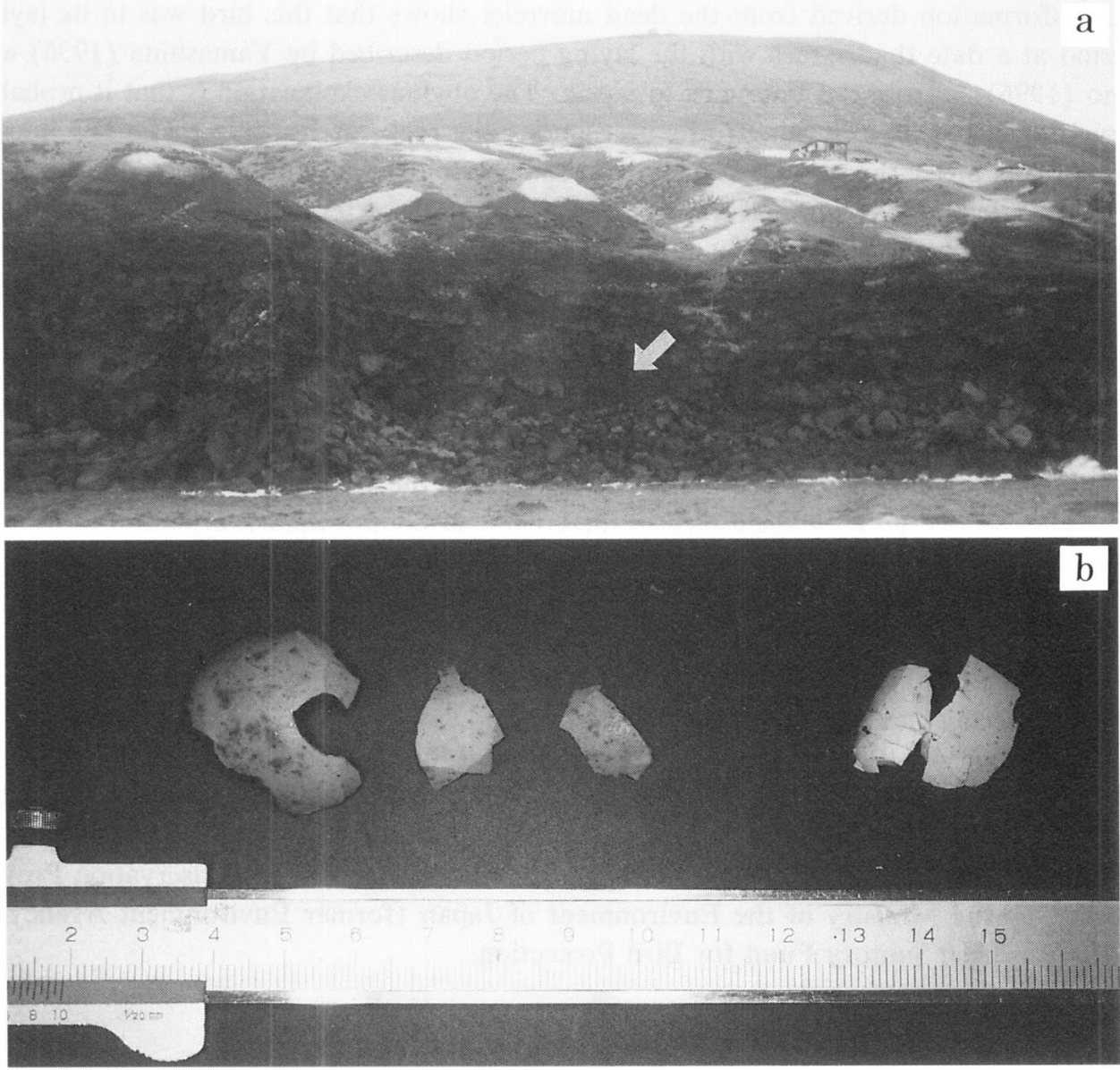

Fig. 1. (a) Site where the dead Japanese Murrelet was found at Hatsune-zaki, Tori-shima (arrow), (b) the eggshell fragments found from the dead body of the Japanese Murrelet. The two pieces on the right were attached to the external abdomen. The three pieces on the left were found in the oviduct.

the bird. Later dissection of the specimen at the Yamashina Institute for Ornithology revealed that the left ovary of this female was developed and measured $19 \times 16 \mathrm{~mm}$, with the largest follicle measuring $10 \mathrm{~mm}$ in diameter, and that it also had fragments of a broken eggshell within the oviduct (Fig. 1b). No other wounds or marks were found during the dissection. External measurements were: total length $252 \mathrm{~mm}$; natural wing length $128.3 \mathrm{~mm}$; exposed culmen $15.4 \mathrm{~mm}$; head length $58.7 \mathrm{~mm}$; bill height at the anterior nares $7.5 \mathrm{~mm}$; bill width at the anterior nares $4.4 \mathrm{~mm}$; gape $20.9 \mathrm{~mm}$; tarsus length $25.2 \mathrm{~mm}$; tail length $39.2 \mathrm{~mm}$; and wing span $425 \mathrm{~mm}$. Body mass was $180 \mathrm{~g}$. This bird is preserved at the Yamashina Institute for Ornithology (YIO) as a study skin (YIO No. 00-0086). 
Information derived from the dead murrelet shows that this bird was in its laying period at a date that agrees with the laying period described by Yamashina (1936) and Ono (1996) as from the February to April. The obvious explanation is that it probably struck a rock while returning to its nest among the rocks of Hatsune-zaki. The impact presumably broke the egg it was just about to lay while it was still in the oviduct causing the bird's death. The eggshell fragments attached to the external abdomen seem to have been pushed out of the cloaca as the bird died.

This was the first time that we had observed this species on the island or in adjacent waters since the start of this project in 1991. On 22-23 February 2001, we again heard calls of this species at around 22:00 near the base camp in Hatsune-zaki. However, we could not determine if these birds were attending nest sites before egg laying or after egg laying. Synthliboramphus murrelets perform nocturnal vocalizations on waters beside colonies and on land before egg laying and throughout the breeding season (Gaston 1992).

The discovery of the dead bird in the laying period and the confirmation of calls in two successive breeding seasons strongly suggest that the Japanese Murrelet breeds on Tori-shima. However, the breeding population, if it exists at all, is thought to be very small considering the scarcity of observations of this species and the abundance of rats (Rattus sp.) on the island, which would prey heavily on the ground nests of small birds such as the Japanese Murrelet.

We thank H. R. Carter of the U. S. Geological Survey and Humboldt State University, K. Ono of Hokkaido Seabird Center, and N. Oka of the Yamashina Institute for Ornithology, for their helpful comments on the manuscript.

The observations were made during the Short-tailed Albatross Conservation Project funded by the Ministry of the Environment of Japan (former Environment Agency of Japan) and the Suntory Fund for Bird Protection.

\section{References}

Aronof, A. E. 1960. Some observations on birds of Torishima. Tori 15: 269-279.

Gaston, A. J. 1992. The Ancient Murrelet: a natural history in the Queen Charlotte Islands. T \& A. D. Poyser, London. 249 pp.

Hasegawa, H. 1984. Status and conservation of seabirds in Japan, with special attention to the Short-tailed Albatross. In Status and conservation of the world's seabirds. (eds. J. P. Croxall, P. G. H. Evans and R. W. Schreiber), pp. 487-500. International Council for Bird Preservation Technical Publication No. 2. ICBP, Cambridge.

Kawada, J. 1956. Bird diary in Torishima. (Torishima tori nikki). Yacho (Wild Birds) 21: 28-37 (in Japanese). Kiyosu, Y. 1952. Synthliboramphus wumizusume, Japanese Auk. In The birds of Japan. Vol. 3. pp. 845-846. Kodansha, Tokyo (in Japanese).

Momiyama, T. 1932. New localities for Japanese birds. Tori 7: 301-328 (in Japanese).

Nettleship, D. N. 1996. Family Alcidae (Auks). In Handbook of the birds of the world. Vol. 3. (eds. J. del Hoyo, A. Elliot and J. Sargatal), pp. 678-722. Lynx edicions, Barcelona.

Ono, Y. 1955. Status of birds on Torishima: particularly of the Steller's Albatross. Tori 14: 24-32 (in Japanese with English abstract).

Ono, K. (ed.) 1995. Status and conservation of rare Alcids in Japan. Japan Alcid Society, Funabashi. 179 pp. (in Japanese).

Ono, K. 1996. Japanese Murrelet. In Basic data book of rare wild aquatic animals and plants in Japan (III). (ed. 
Fishery Agency Japan). pp. 514-519. Japan Fisheries Resource Conservation Association, Tokyo (in Japanese).

Ono, K. 1998. Japanese Murrelet. In Data book of rare wild aquatic animals and plants in Japan. (ed. Fishery Agency Japan). pp. 422-423. Japan Fisheries Resource Conservation Association, Tokyo (in Japanese).

Ornithological Society of Japan (OSJ). 1942. A hand-list of Japanese birds. Third and revised ed. OSJ, Tokyo. $238 \mathrm{pp}$.

Ornithological Society of Japan (OSJ). 1958. A hand-list of Japanese birds. Fourth and revised ed. OSJ, Tokyo. $264 \mathrm{pp}$.

Ornithological Society of Japan (OSJ). 1974. Check-list of Japanese birds. Fifth and revised ed. Gakken, Tokyo. $364 \mathrm{pp}$.

Sato, F., Momose, K., Tsurumi, M., Hiraoka, T., Mitamura, A. \& Baba, T. 1998. The first breeding success in the Short-tailed Albatross colony restoration project on Tori-shima, using decoys and vocal lure. J. Yamashina Inst. Ornithol. 30: 1-21 ( in Japanese with English abstract).

Yamashina, Y. 1936. Habits of Janthoenas janthina and Synthliboramphus wumizusume in the Seven Islands of Izu. Tori 9: 222-231 (in Japanese).

Yamashina, Y. 1942. Birds of the Seven Islands of Izu. Tori 11: 191-270 (in Japanese).

\section{伊豆諸島鳥島におけるカンムリウミスズメの繁殖の可能性}

カンムリウミスズメは日本列島近海抢よび韓国南部の小島で繁殖しているウミスズメ類で, 生息数が少なく絶滅が危惧されている。かつてカンムリウミスズメは鳥島で繁殖の記録があ り, 同島で 1930 年から 1935 年にかけて採集された卵標本とヒナおよび成鳥の剥製標本がそれ を裏付けている。しかし近年では，本種の繁殖は確認されていない。

2000 年 3 月 4 日早朝, 筆者らは鳥島西部・初寝崎の宿泊地の周辺で数羽の本種の声を確認 し, 同日, 付近の断崖下 (海抜約 $20 \mathrm{~m}$ ) の岩場で成鳥 1 羽の新鮮な死体を発見した。この死体 には腹部に卵款の破片が付着していた。解剖の結果, 本個体は雌で, 卵巣が発達しており, 輸 卵管内には卵款の破片があった。この個体は産卵期にあり，島へ帰巣する際に岩に衝突し，そ の衝撃で輸卵管内の卵が割れて死亡したものと考えられた。さらに 2001 年 2 月 22 及び 23 日 にも本種の声を確認した。

本種の繁殖期における卵を持った死体の発見と 2 年連続しての鳴き声の確認は, 少数の本種 が鳥島で繁殖している可能性を強く示唆するものである。

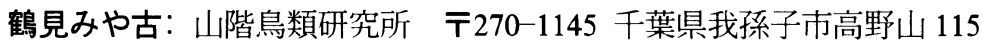

E-mail: tsurumi@yamashina.or.jp

佐藤 文男：山階鳥類研究所 $=270-1145$ 千葉県我孫子市高野山 115

E-mail: sato@yamashina.or.jp

平岡 考：山階鳥類研究所 $\mathbf{T} 270-1145$ 千葉県我孫子市高野山 115

E-mail: hiraoka@yamashina.or.jp

前山 亮：山階鳥類研究所 $\overline{\mathbf{T}} 270-1145$ 千葉県松戸市小金原 8-19-16 